\title{
Phytochemical and Antioxidant Potential of Indian Flora
}

\author{
Jyothi Kanagaraj, Hariharan Prabakaran, Venkatesan Chandran
}

\begin{abstract}
- the plant kingdom serves as a reservoir of many organic compounds that have been used for many therapeutic purposes. Oxidative reaction plays major part of our life, cause production of reactive oxygen species. The aim of this study was to investigate the antioxidant activity of ethanol and ethyl acetate extract of two potential medicinal plants like Achyranthes aspera and Cassia auriculata. The crude extract of the plant was subjected to preliminary qualitative analysis to identify the major functional groups and phytochemical substances like alkaloids, flavonoids, phenolic compounds, carbohydrates, and proteins. Antioxidant activities of the plant extract was screened by free radical scavenging activity (DPPH). Dried leaf and stem powder of these medicinal plant was extracted and concentrated to yield a dry residue. Our findings indicate that Achyranthes aspera possess a significant antioxidant property followed by Cassia auriculata.
\end{abstract}

Keywords: Achyranthes aspera, Antioxidant, Cassia auriculata, DPPH

\section{INTRODUCTION}

$\mathbf{P}_{\text {lants used as medicines since time immemorial. }}$ Medicinal plants have been identified and used in traditional medicines, since ancient periods. Most plants of medicinal value having rich sources of secondary metabolites, and are potential sources of valuable drugs and bioreactive product. Antibacterial properties of a variety of plant parts have been reported in earlier studies for some medicinal plants. [1]. Medicinal plants are commonly used in non industrialized societies, because of easier availability and cheaper comparing to modern medicines. Plant medicines are widely used in and around the world, particularly in countryside as it is the lone source of health care for people, in the developing world [2]. Pharmacologically active plant extracts can interact with conventional drug, both because they may provide an increased dose of similar compounds, and some phytochemicals interfere with the body systems [3].

The medicinal plants selected for our study includes, Cassia auriculata and Achyranthes aspera. Cassia auriculata possess hepatoprotective, antipyretic, antiperoxidative, antidiabetic and antihyperglyceamic activity and is also used as a traditional system of medicine for female antifertility [4].

Revised Manuscript Received on December 15, 2019.

*Correspondence Author

Jyothi Kanagaraj *, Department of Biotechnology, Kalasalingam Academy of Research and Education, Krishnankoil.

Email: Jyothi.k@klu.ac.in

Hariharan Prabakaran, Department of Biotechnology, Kalasalingam Academy of Research and Education, Krishnankoil.

Email: haritakker@gmail.com

Venkatesan Chandran, Department of Biotechnology, Kalasalingam Academy of Research and Education, Krishnankoil.

Email: cvenkatesan0524@gmail.com
Achyranthes aspera, a common plant, found in abundance in wastelands. This plant is commonly used in traditional medicine for curing bleeding diseases, in facilitating delivery, boils, asthma, bronchitis, cold, cough, renal complications etc. [5].

In biological systems, the free radicals generated during metabolic process, and the free radical chain reactions are formed in the mitochondrial respiratory chain, from drugs, chemicals and atmospheric pollutants. [6,7]. Lipid peroxidation occurs due to oxygen free radical, which in turn stimulates the protein glycation, enzyme inactivation and altering the structural orientation of biological membranes. [8]. Infection and Infectious diseases are the world's most leading cause of premature deaths [9].

Considering the medicinal significance of the plant territory, it is a need to understand the role of antioxidant activity and free radical scavenging properties in which there is emergent role of free radicals in the progression of ailments. The present investigation is an effort to identify the protective effects of two traditionally used medicinal plants that are known to have curative effects of many disorders. Investigating the medicinal benefits of these plants, may help the researchers to improve their understanding the complex mechanism of medicinal plants.

\section{MATERIALS AND METHODS}

\section{A. Sample collection}

The plants Cassia auriculata and Achyranthes aspera was collected in and around KARE, Tamil nadu, India and was taxonomically identified by the department of botany, American College, Madurai. In the laboratory, the different parts of plant sample (leaf and stem) were washed with freshwater.

\section{B. Preparation of solvent extracts}

The cleaned, healthy plant materials are cut in to small sections and dried under shade for three weeks. The dried plant material was grind into fine powder using an electric grinder. Powder so obtained was used for extraction. Extraction was carried out using $5 \mathrm{gm}$ of each sample coarsely powdered plant material with $50 \mathrm{ml}$ of solvent and kept for 48 hrs with slight shaking. Here, ethanol and ethyl acetate (HPLC grade) were used as a solvent for extraction; different solvents elute different compounds from the sample. The extracts were filtered, to get filtrate as extracts and dried to concentrate the samples. The residual powder was weighed and re dissolved in the respective solvents to get a final concentration $1 \mathrm{mg} / \mathrm{ml}$. 


\section{Phytochemical and Antioxidant Potential of Indian Flora}

The powder was stored in airtight containers under refrigeration condition.

\section{Preliminary Phytochemical Analysis}

The crude extract of Cassia auriculata and Achyranthes aspera were subjected to qualitative phytochemical analysis for identifying major functional groups and chemical constituents of plants such as alkaloids, phenolic compounds, flavonoids, carbohydrates and proteins $[10,11]$.

\section{Determination of antioxidant activity}

Total antioxidant activity is analyzed quantitatively and expressed in terms of equivalents of ascorbic acid. DPPH assay were measured following the method of Shimada [12] with a slight modification of Cakir. [13]. Briefly, to $2 \mathrm{ml}$ extracts of varying concentrations (100-600 $\mu \mathrm{g} / \mathrm{ml})$ of Cassia auriculata and Achyranthes aspera, added $1 \mathrm{ml}$ of DPPH solution (methanolic $0.1 \mathrm{mM} \mathrm{DPPH}$ ) and was shaken vigorously. The absorbance was measured by using UV Spectrophotometer at $517 \mathrm{~nm}$, using ascorbic acid as standard. The experiments were performed in triplicate. The scavenging activity of the plant extracts at corresponded intensity of quenching DPPH decreases the absorbance of the mixture and depicts higher free radical scavenging activity. The difference in absorbance of the test sample to the control (DPPH in ethanol) was calculated and expressed as (\%).The below equation was used to calculate the DPPH assay.

$\%$ scavenging $=$ Absorbance of control- absorbance of test sample $X 100$ Absorbance of control

\section{E. Data Analysis}

Results were expressed as mean $\pm \mathrm{SD}$. The result of this study was based on the experiments performed in triplicate. To check the linearity for the mean absorbance, regression analysis was followed. Significance between the concentrations was studied using ANOVA. Difference in values was measured to be significant if $\mathrm{P}$ value $<0.05$.

\section{RESULT AND DISCUSSION}

Antioxidant nature of various medicinal plants is being reported from many parts of the world. It was reported by the World Health Organization (WHO) that $80 \%$ of the world's population used the active constituents of plant extracts in traditional therapies. As the plant territory represents a major reservoir of organic compounds, and has been used for many medicinal purposes. Most of the plant extract have been proved to benefit human health by scavenging free radicals. The secondary metabolites found in the plant samples play a major role as antioxidant activity [14]. Hence, in this study the extracted plant samples were studied for their antioxidant efficacy.

\section{A. Phytochemical Analysis}

The extracts obtained from extraction of plant parts were subjected to different phytochemical tests to expose the presence of phytochemicals. The preliminary phytochemical analysis of the leaves and stems of Cassia auriculata and Achyranthes aspera was depicted in Table 1. It was revealed that in both ethanol and ethyl acetate extract was found to show the presence of alkaloids, carbohydrates and flavonoids.
Leaf and stem of both the plants contained phenolic compound in ethanol extract. Protein was not found in the stem of Achyranthes aspera in both extracts. These secondary metabolites of medicinal plants contribute towards the biological activities such as, antidiabetic, antimicrobial, antioxidant, anti-inflammatory, anticarcinogenic etc. [15].

\section{B. Antioxidant Studies}

Numerous antioxidant assays designed to measure antioxidant potency of samples among these DPPH radical scavenging assay is widely used for screening large number of samples of varying polarity. DPPH is a stable synthetic radical with purple colour which in the presence of antioxidant gets reduced due to the donation of hydrogen atom to free radical resulting in the loss of purple colour and thereby inhibiting the propagation of lipid peroxidation [16].

TABLE- I: Phytochemical analysis of Cassia auriculata and Achyranthes aspera

\begin{tabular}{|c|c|c|c|c|}
\hline \multirow{2}{*}{ Variable } & \multicolumn{2}{|c|}{$\begin{array}{l}\text { Cassia auriculata } \\
\text { (leaf) }\end{array}$} & \multicolumn{2}{|c|}{$\begin{array}{l}\text { Achyranthes } \\
\text { aspera (leaf) }\end{array}$} \\
\hline & Ethanol & $\begin{array}{l}\text { Ethyl } \\
\text { acetate }\end{array}$ & Ethanol & $\begin{array}{l}\text { Ethyl } \\
\text { acetate }\end{array}$ \\
\hline $\begin{array}{l}\text { Carbohydrates } \\
\text { (Molisch Test) }\end{array}$ & + & + & + & + \\
\hline $\begin{array}{l}\text { Alkaloids } \\
\text { (Mayer's Test) }\end{array}$ & + & + & + & + \\
\hline $\begin{array}{l}\text { Flavonoids } \\
\text { (Ferric chloride } \\
\text { Test) }\end{array}$ & + & + & + & + \\
\hline $\begin{array}{l}\text { Phenolic } \\
\text { compounds } \\
\text { (Phenol Test) }\end{array}$ & + & - & + & - \\
\hline $\begin{array}{l}\text { Proteins } \\
\text { ( Biuret Test) }\end{array}$ & + & - & + & - \\
\hline \multirow{2}{*}{ Variable } & \multicolumn{2}{|c|}{$\begin{array}{l}\text { Cassia auriculata } \\
\text { ( stem) }\end{array}$} & \multicolumn{2}{|c|}{$\begin{array}{l}\text { Achyranthes } \\
\text { aspera ( stem) }\end{array}$} \\
\hline & Ethanol & $\begin{array}{l}\text { Ethyl } \\
\text { acetate }\end{array}$ & Ethanol & $\begin{array}{l}\text { Ethyl } \\
\text { acetate }\end{array}$ \\
\hline $\begin{array}{l}\text { Carbohydrates } \\
\text { (Molisch Test) }\end{array}$ & + & + & + & - \\
\hline $\begin{array}{l}\text { Alkaloids } \\
\text { (Mayer's Test) }\end{array}$ & + & + & + & + \\
\hline $\begin{array}{l}\text { Flavonoids } \\
\text { (Ferric chloride } \\
\text { Test) }\end{array}$ & + & - & + & + \\
\hline $\begin{array}{l}\text { Phenolic } \\
\text { compounds } \\
\text { (Phenol Test) } \\
\end{array}$ & + & - & + & - \\
\hline $\begin{array}{l}\text { Proteins ( } \\
\text { Biuret Test) }\end{array}$ & + & - & - & - \\
\hline
\end{tabular}

Table 1: $(+)=$ Presence, $(-)=$ Absence

The leaf and stem of two different plants in different extracts were studied for their antioxidant ability and the results were depicted in Table 2 and 3. DPPH was significantly decreased with the addition of the extract in a concentration dependent manner. The plant extracts induced a quick diminish in the optical density.

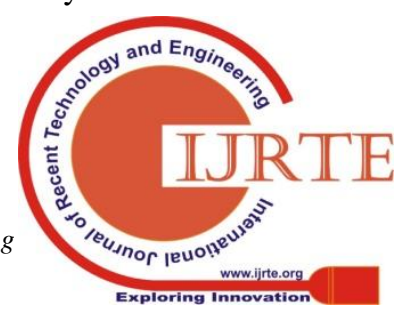


This decline in absorbance of DPPH radical was due to the antioxidant property of the plant extract which can be noticed as a change in colour from purple to yellow.

Antioxidant study of ethanol extract of Cassia auriculata and Achyranthes aspera for leaf and stem of the plants was depicted in Table 2. The antioxidant activities of leaf exhibited a higher activity in both the plants in a concentration dependant manner.

TABLE II: Antioxidant assays of leaf and stem of Cassia auriculata and Achyranthes aspera in ethanol extract

\begin{tabular}{|c|c|c|c|c|c|}
\hline \multirow{3}{*}{ S.No } & \multirow{3}{*}{$\begin{array}{l}\text { Concentration } \\
(\mu \mathrm{g} / \mathrm{ml})\end{array}$} & \multicolumn{4}{|c|}{ Antioxidant activity (\%) } \\
\hline & & \multicolumn{2}{|c|}{ Cassia auriculata } & \multicolumn{2}{|c|}{ Achyranthes aspera } \\
\hline & & Leaf & Stem & Leaf & Stem \\
\hline 1 & 100 & $\begin{array}{l}42.85 \pm \\
1.65\end{array}$ & $37.04 \pm 0.25$ & $67.63 \pm .23$ & 48.731 .82 \\
\hline 2 & 200 & $\begin{array}{l}48.5 \pm \\
2.5^{*}\end{array}$ & $\begin{array}{l}40.28 \pm 1.97 \\
*\end{array}$ & $73.28 \pm 0.4 *$ & $\begin{array}{l}55.65 \\
\pm 0.55^{*}\end{array}$ \\
\hline 3 & 300 & $\begin{array}{ll}53 & \pm \\
1.0^{*} & \end{array}$ & $\begin{array}{l}44.85 \pm \\
1.08 *\end{array}$ & $78.58 \pm .38 *$ & $\begin{array}{l}59.33 \pm \\
.98^{*}\end{array}$ \\
\hline 4 & 400 & $\begin{array}{l}56 \pm \\
1.78^{*}\end{array}$ & $\begin{array}{l}48.73 \pm \\
0.86^{*}\end{array}$ & $\begin{array}{l}82.47 \pm 0.58 \\
*\end{array}$ & $\begin{array}{l}64.74 \pm \\
.98^{*}\end{array}$ \\
\hline 5 & 500 & $\begin{array}{l}61 \\
\pm 1.98 *\end{array}$ & $\begin{array}{l}50.16 \pm \\
0.94^{*}\end{array}$ & $85.71 \pm .79 *$ & $\begin{array}{l}72.22 \\
\pm 1.20 *\end{array}$ \\
\hline 6 & 600 & $\begin{array}{l}62.5 \pm \\
35^{*}\end{array}$ & $\begin{array}{l}53.55 \pm \\
1.26^{*}\end{array}$ & $87.75 \pm .46 *$ & $\begin{array}{l}79.34 \pm \\
0.89 *\end{array}$ \\
\hline
\end{tabular}

Table 3: Antioxidant activities of leaf and stem of Cassia auriculata and Achyranthes aspera in ethyl acetate extract

\begin{tabular}{|c|c|c|c|c|c|}
\hline \multirow{3}{*}{ S.No } & \multirow{3}{*}{$\begin{array}{l}\text { Concent } \\
\text { ration } \\
(\mu \mathrm{g} / \mathrm{ml})\end{array}$} & \multicolumn{4}{|c|}{ Antioxidant activity (\%) } \\
\hline & & \multicolumn{2}{|c|}{ Cassia auriculata } & \multicolumn{2}{|c|}{ Achyranthes aspera } \\
\hline & & Leaf & Stem & Leaf & Stem \\
\hline 1 & 100 & $40.43 \pm 1.23$ & $27.04 \pm 0.25$ & $45 \pm 1.3$ & $\begin{array}{l}30.73 \\
\pm 1.02 \\
\end{array}$ \\
\hline 2 & 200 & $\begin{array}{l}43.50 \pm \\
0.86^{*}\end{array}$ & $34.28 \pm 1.07 *$ & $\begin{array}{l}47.5 \pm \\
1.23^{*}\end{array}$ & $\begin{array}{l}34.65 \pm \\
0.57^{*}\end{array}$ \\
\hline 3 & 300 & $\begin{array}{l}46.28 \pm \\
1.28^{*}\end{array}$ & $38.85 \pm 1.08^{*}$ & $\begin{array}{l}52.5 \pm \\
0.95^{*}\end{array}$ & $\begin{array}{l}42.33 \pm \\
0.98^{*}\end{array}$ \\
\hline 4 & 400 & $\begin{array}{l}50.14 \pm \\
0.97 *\end{array}$ & $42.73 \pm 0.86^{*}$ & $\begin{array}{l}56.12 \pm \\
1.02 *\end{array}$ & $\begin{array}{l}45.74 \pm \\
1.50^{*}\end{array}$ \\
\hline 5 & 500 & $\begin{array}{l}53.02 \pm \\
1.39 *\end{array}$ & $44.16 \pm 0.94 *$ & $\begin{array}{l}60.5 \pm \\
1.24^{*}\end{array}$ & $\begin{array}{l}47.22 \\
\pm 1.20^{*}\end{array}$ \\
\hline 6 & 600 & $\begin{array}{l}55.55 \pm \\
1.37 *\end{array}$ & $46.55 \pm 1.26^{*}$ & $63 \pm 0.7 *$ & $\begin{array}{l}50.34 \pm \\
0.47^{*}\end{array}$ \\
\hline
\end{tabular}

Antioxidant activity of Cassia auriculata and Achyranthes aspera, of ethyl acetate extract, for leaf and stem of the plants was exposed in Table 3. The antioxidant activities of leaf and stem of Cassia auriculata was 55\%, and $46 \%$, respectively and for Achyranthes aspera, the leaf was $63 \%$ and stem was $50 \%$. Here, we observed that the antioxidant activity was rich in leaves followed by stem in ethanol as well as ethyl acetate extract in both plants.

Due to the scavenging ability of Achyranthes aspera and Cassia auriculata, the concentration of DPPH radical was found to be decreased. Achyranthes aspera and Cassia auriculata showed significant free radical scavenging activity at a higher concentration of $600 \mu \mathrm{g} / \mathrm{ml}$.

\section{CONCLUSION}

Scientific investigation of natural resources for their therapeutic and food value is gaining more importance. In this regards, the result of our study revealed the presence of phytochemicals among two different parts of the same plant with leaf possessing highest flavonoids, alkaloids and phenolic content in the ethanolic extract of Cassia auriculata as well as Achyranthes aspera. From the results of antioxidant activity, it was concluded that the leaves found to be effective in DPPH radical scavenging activity in different solvent plant extracts compared to stems in Cassia auriculata and Achyranthes aspera. The solvent extract of selected plants is the authentic choice to protect from oxidation.

\section{ACKNOWLEDGMENT}

The authors would like to thank the Department of Biotechnology and International Research Centre, KARE.

\section{REFERENCES}

1. N.R. Bhalodia and V.J. Shukla V J., Antibacterial And Antifungal Activities from Leaf Extracts Of Cassia Fistula L. An Ethno Medicinal Plant. Journal of Advanced Pharmaceutical Technology and Research, 2(2):2011, pp.104-109.

2. S.Karumaran, S. Nethaji and R. Rajakumar., Antimicrobial and antioxidant activity of leaf extracts of Aegle marmelos. Advances in Applied Science Research. 7(3): 2006, pp. 205-208.

3. D.O. Kennedy And E.L.Wightman., Herbal Extracts And Phytochemicals: Plant Secondary Metabolites And The Enhancement Of Human Brain Function. Advances In Nutrition, 2(1):2011, pp. $32-50$

4. L. Pari and M. Latha., Antihyperglyceamic effect of Cassia auriculato in experimental diabetes and its effects on key metabolic enzymes involved in carbohydrate metabolism. Clinical and Experimental Pharmacology and Physiology, 30: 2003, pp. 38-43.

5. B.G. Abi, S.A.Mohamed and R.Jaya Santhi., Antioxidant and antibacterial activity of Achyranthes aspera: An in vitro study. Annals of Biological Research, 2 (5): 2011, pp.662-670.

6. T. Hussain, B. Tan, Y. Yin, F. Blachier, M C B. Tossou and N. Rahu. Oxidative Stress and Inflammation: What Polyphenols Can Do for Us? Oxidative Medicine and Cellular Longevity, 2016, pp. 1-9.

7. L.A. Pham-Huy, Hua $\mathrm{He}$ and C. Pham-Huy., Free Radicals, Antioxidants in Disease and Health. International Journal of Biomedical Science, 4(2):2008, pp.89-96.

8. M. Nita M and A. Grzybowski., The Role of the Reactive Oxygen Species and Oxidative Stress in the Pathomechanism of the Age-Related Ocular Diseases and Other Pathologies of the Anterior and Posterior Eye Segments in Adults. Oxidative Medicine and Cellular Longevity, 2016: 3164734.

9. S.Semenya and A.Maroyi A., Medicinal Plants Used for the Treatment of Tuberculosis by Bapedi Traditional Healers in Three Districts of the Limpopo Province, South Africa. African Journal of Traditional, Complementary and Alternative Medicines, 10(2): 2013, pp. 316-323.

10. S. Chaudhary, A. Negi and V. Dahiya .,The study of in vitro antimicrobial activity and phytochemical analysis of some medicinal plants in chamoli garhwal region. Pharmacognosy Journal, 2 (12) 2010, pp. 481-485.

11. M. Kamalineja, F. Mojab, N. Ghaderi and H,R,Vahidipour., Phytochemical screening of some species of Iranian plants. Iranian Journal of Pharmaceutical Research, 2: 2003, pp. 77-82.

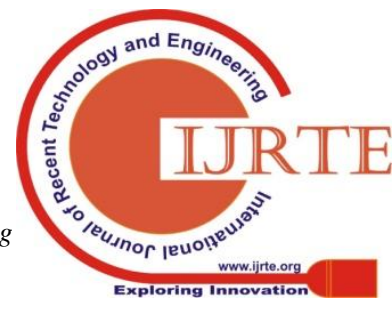




\section{Phytochemical and Antioxidant Potential of Indian Flora}

12. K.Shimada, K. Fujiyama, K.Yahara and T.Nakamura., Antioxidative properties of xanthan on the autoxidation of soybean oil in cyclodextrin emulsion. Journal of Agriculture and Food Chemistry, 40 (6):1992, pp. $945-948$.

13. Cakir, A. Mavi , A.Yildirim , M.E.Duru, M.Harmandar and C.Kazaz., Isolation and characterization of antioxidant phenolic compounds from the aerial parts of Hypericum hyssopifolium L. by activity-guided fractionation. Journal of Ethanopharmacology, 87 (1): 2003, pp. 73-83.

14. K N.Purushotham, H.V. Annegowda H V, N,K Sathish, B. Ramesh and S. M. Mansor., Evaluation of phenolic content and antioxidant potency in various parts of Cassia auriculata L.: A traditionally valued plant. Pakistan Journal of Biological Sciences, 17(1): 2014, pp. 41-48.

15. Y.Manjulika , C.H. Sanjukta, Sharad K G and W. Geeta., Preliminary Phytochemical screening of six medicinal plants used in traditional medicine. International Journal of Pharmacy and Pharmaceutical Sciences, 6 (5): 2014, pp. 539-542.

16. A. Lugasi , P. Horvahovich and E. Dworschak E .,Additional information to the in vitro antioxidant activity of Ginkgo biloba L. Phytotherapy Research, 13 (2):1999, pp. 160-162. 